\title{
The Pillars of Dutch Naval Shipbuilding after $1945^{1}$
}

\section{Alan Lemmers}

Cet article clarifie l'origine et l'organisation de la construction moderne des navires de guerre dans les Pays-Bas. Il révise les programmes de flotte et les développements industriels durant la période de la Guerre Froide, et finalement il examine les développements récents depuis la destruction du Mur de Berlin. Il sera soutenu que la construction de navires néerlandaises repose sur quatre piliers, desquels trois étaient établis pendant la période 1825-140 avant la Deuxième Guerre Mondiale et le quatrième--l'alliance stratégique - a servi comme principe guidant après 1945. Le long du chemin la marine de guerre et l'industrie néerlandaises ont profité et souffert de tournés politiques (globales) et économiques, pour finalement arriver au croisement où nous nous trouvons aujourd'hui.

Ever since the Second World War the Royal Netherlands Navy, (RNLN), has been an esteemed partner of the US Navy and the Royal Navy. For their part, the Dutch government and the Dutch armed forces keenly treasured their UK and US alliances, the seeds of which had been planted during the war. Immediately after the war the Netherlands still cherished certain global commercial and territorial ambitions which demanded a maritime power that the small European nation could hardly sustain on its own. Moreover it wanted to preserve its privileged position as political and military equal beside its

\footnotetext{
1 An earlier version of this paper was presented at the IMEHA Conference in Gent, Belgium, in the summer of 2012, in the session on naval shipbuilding of small and medium-sized navies. I am much indebted to ir. Jaap Huisman, Director Platform Technology, Royal Netherlands Navy, and to ir. Willem PJ Laros, senior advisor of the Damen Shipyard Group, for their invaluable information and advice. Many thanks also to drs. Anselm J van der Peet and dr. Thijs BrocadesZaalberg of the Netherlands Institute of Military History.
} 
former wartime allies. This of course came at the price of a proportional Dutch military effort in which naval technology played an important role.

As an industry shipbuilding is often also pursued by a nation to stimulate economic and technological development. It functions as the backbone for the development of downstream and upstream industries of suppliers and subcontractors, with far-going effects on shipping and trade, employment, education, national wealth and income. ${ }^{2}$ Years before the end of the war the shipbuilding sector was already targeted by Netherlands government in exile as a major instrument to recover from the war's destruction. Since 1945 naval building programs were regularly used to safeguard economic stability.

This paper has several aims. First, it will clarify how the origin and organization of modern naval shipbuilding in the Netherlands evolved from historic shipbuilding patterns. Second, it will examine the relationship of fleet programs and the industrial developments in the Cold War period. Third and finally, it will review developments since the fall of the Berlin Wall. It will be argued that Dutch naval shipbuilding rests on four pillars, of which three were erected in the pre-war period (1825-1940) and the fourth - strategic alliance served as guiding principle after 1945. Along the way both the Dutch navy and industry profited and suffered from global political and economic turns, thus creating today's conditions.

\section{THE LAY OF THE LAND (PRE-1945)}

In the course of history, naval shipbuilding in the Netherlands has swung from private enterprise to state-owned production and back again. After the disastrous First Anglo-Dutch War (1652-1654), the five provincial admiralties that formed the Republic's navy reverted from the extensive use of hired and converted merchantmen to the construction and upkeep of a standardized and purpose-built naval force, including extensive maintenance facilities. ${ }^{3}$ In 1795 , the navy was centralized but maintained its five building yards. However, economic conditions had changed and the extensive dockyard facilities weighed on the national budget. Responding to persistent calls for reduction, they were closed down one after the other: from 1868 the Amsterdam Navy dockyard was the last that remained in operation until it also closed its gates in 1915. From that day new warships were exclusively commissioned from private yards.

However, in the course of this process the now Royal Netherlands Navy managed to keep a firm grip on the design and the production of its materiel.

\footnotetext{
${ }^{2}$ Duck Hee Won, A Study of Korean Shipbuilders' Strategy for Sustainable Growth (Seoul, 2010), 7.

${ }^{3}$ Alan Lemmers, Van werf tot facilitair complex: 350 jaar marinegeschiedenis op Kattenburg, (The Hague, 2005, 3rd reprint 2013), 22-26.
} 
The ship plans almost exclusively were provided by navy engineers and likewise for many details. From the appearance of steam power in the 1820 s for instance, the navy left the production of engines and propulsion gear to private construction firms, yet each one of these propulsion trains - bar one or two exceptions - was designed by navy engineers. The ties between the RNLN and the construction companies were very close: some of the major factories were founded by (former) navy engineers, while many young navy engineers received part of their training at these firms. The Nederlandsche Stoomboot Maatschappij Fijenoord in Rotterdam, founded in 1823 by former navy lieutenant Gerard Moritz Röntgen (1795-1852), was for 150 years one of the main suppliers of steam engines and in the early decades it provided training for navy engineers and officers. It was to become the important 20th-century yard, Wilton-Fijenoord. ${ }^{4}$ The Koninklijke Fabriek van Stoom- en andere Werktuigen, founded in 1825 by entrepreneur Paul van Vlissingen (1797-1876), lay next to the Amsterdam navy dockyard, to which it supplied engines as well as the practical schooling of officers and yard personnel. The Koninklijke Fabriek was the forerunner of both the second important 20th-century yard, Nederlandsche Dok en Scheepsbouw Maatschappij, (NDSM), and also of the engineering firm Werkspoor. ${ }^{5}$ The yard, De Schelde, the third company that should be mentioned here, was founded in 1875 at the initiative of RNLN Chief Surveyor B.J. Tideman (1834-1883) to resolve the unemployment problem of Flushing after the closure of the navy dockyard in that town in $1868 .{ }^{6}$ Originally intended for commercial shipping, it soon also received orders from the RNLN. Now part of the Damen conglomerate, today it is the last remaining yard in the country to build for the navy. The RNLN of course represented only one market segment for these companies that also targeted commercial and civil sectors in other diverse fields: commercial shipbuilding and ship-owning, agricultural, chemical and industrial machinery, mining and railway engineering, to mention just a few. In times of financial difficulties these firms would turn to the RNLN for support, which was often provided in the form of building orders.

Although naval construction was entirely transferred to the private sector, the core designs were still all developed by the Construction Department of the RNLN. They specialised in the translation of operational needs into material requirements. The contracts for all the large projects generally went to one of a select number of firms, some of which have been mentioned above. However, when the building program of the navy was scrapped by Parliament in 1923 - due to both the pacifist climate and the sorry state of the treasury - the industry ran into hard times. It was not until 1930 that new fleet plans were initiated, but by then both the country and the shipbuilding sector were suffering

\footnotetext{
${ }^{4}$ MG de Boer, Het leven en bedrijf van Gerard Moritz Roentgen, ( s.1., 1923), passim.

${ }^{5}$ MG de Boer, Honderd jaar machine-industrie op Oostenburg (Gedenkboek Werkspoor), (Amsterdam, 1927), passim.

6 JM Dirkzwager, Dr. B.J. Tideman (1834-1883), grondlegger van de modern scheepsbouw in Nederland, (Leiden, 1970), 44-79.
} 
from the worldwide economic crisis. To cut costs while retaining their vital designing expertise - which for the navy was restricted to detailed drafting after contract - the four major shipyards and one engineering firm in 1935 pooled their design sections into a separate company, the Nederlandsche Vereenigde Scheepsbouw Bureaux (Netherlands United Shipbuilding Bureaux Ltd.) or Nevesbu for short. ${ }^{7}$

In essence Nevesbu was no more than a detailed drafting section, where the plans of the navy's Construction Department were worked out ahead of the selection of the shipbuilder. ${ }^{8}$ For its shareholders - the combined shipyards Nevesbu also actively canvassed for foreign naval orders. The firms in this joint enterprise were the shipyards De Schelde in Flushing, the Rotterdam Dockyard Company (RDM), and the Rotterdam shipyard and engineering works WiltonFijenoord, and the Netherlands Dock and Shipbuilding Company (NDSM), and the large engineering works Werkspoor Ltd. NDSM and Werkspoor were both located in Amsterdam. The RDM, the only firm not mentioned before, was founded in Delfshaven near Rotterdam in 1856 by Scottish engineer Duncan Christie; from the start the company occasionally executed orders for the RNLN, but it became regularly involved in naval shipbuilding only in the 1930s and then soon specialised in submarines. Although the Netherlands government in essence adhered to the principle of public tender, the companies mentioned above were the prime (and above a certain tonnage the sole) suppliers of the RNLN.

With the advent of steam, iron and steel in the nineteenth century, the Netherlands had also found itself at a disadvantage for want of raw materials and heavy industry. Moreover its size and economy did not allow for a large defence apparatus, but the country tried to make up with the most modern equipment it could get, especially for the navy - not with the largest or most powerful ships, but definitely state-of-the-art. In many cases the navy followed a strategy of first purchasing a prototype abroad, manufacturing under license or copying, and then developing its own improved designs: British steam engine and screw propulsion technology, British and French ironclad technology and American submarine technology are just three of many examples before the First World War. In the course of the years the RNLN acquired such know-how, that it confidently developed its own Dutch style. Although naval artillery after 1865 (including torpedoes) was left entirely to foreign production, from the early 1900s the RNLN also developed targeting and guidance systems of its own. ${ }^{9}$

\footnotetext{
7 Hubert V Quispel, The Job and the Tools, (Rotterdam, 1960), 129-171.

8 In later years Nevesbu would also take on detailed engineering projects.

9 With the introduction of rifled artillery the RNLN procured its main armament first from the Scottish firm Armstrong, from the 1880s from Krupp in Germany and after the First World War from the Swedish arms manufacturer Bofors, which by then was in Krupp hands. An inter-war exception to this rule was the Dutch firm Hollandsche Industrie Maatschappij, but this was actually a front for the German arms manufacturer Rheinmetall dodging the Versailles treaty -
} 
Monitoring foreign developments did not prevent the Dutch navy from adopting home-grown innovations or sailing its own course. ${ }^{10}$ Dutch submarines in the interwar years for instance ran ahead of the rest of the world with electrically welded hulls, the snorkel, a diesel trimming system, a primitive airco and a torpedo launching system without bubbles, while the unique post1945 "three-cylinder submarine" set new records for depth and endurance. ${ }^{11}$ Since 1825 the RNLN had taken up the position of (innovative) partner of the shipbuilding and engineering industry: during the entire 19th century for instance naval architecture in the Netherlands was taught exclusively by personnel of the Construction Department. ${ }^{12}$ In 1876 Chief Surveyor Tideman erected a model testing tank at the Amsterdam navy dockyard, the second in the world and the first on the continent, which operated successfully (and not exclusively for the RNLN) until $1890 .^{13}$ In 1919 the navy explored the possibilities for a new towing tank, but it was only in 1929 that the industry was willing to partake in the venture. ${ }^{14}$ The founding of the testing station (today the Maritime Research Institute Netherlands or "MARIN"), in which the RNLN had an important share, nearly coincided with the establishment by law of the Nederlandse Organisatie voor Toegepast Natuurwetenschappelijk Onderzoek (Netherlands Organization of Applied Scientific Research or TNO) in 1932. Both organizations are entirely independent from the state, yet from the outset they had and still have the specific task to support government organizations (mainly Defence) and private industry with innovative, practicable research. ${ }^{15}$ Together with the armed forces, some universities and private industry, TNO was involved in the development of radar technology just before the war. ${ }^{16}$ One

Roy Kreeftmeijer, "De gaten in de schijf: geschutaankopen voor de Koninklijke Marine 19201930”, Tijdschrift voor Zeegeschiedenis,( 2008/2), 512-168.

10 Alan Lemmers, Techniek op schaal. Modellen en het technologiebeleid van de marine 17251885, (Amsterdam, 1996), discusses many examples both of technology import and home-grown innovations in the 18th and 19th century.

${ }^{11}$ JJW van Waning and FLM Nabbe (eds.), De Nederlandse Onderzeedienst 1906-1966, (The Hague, 1966), passim; KHL Gerretse and JJA Wijn, Drie-cylinders duiken dieper. De onderzeeboten van de Dolfijn-klasse van de Koninklijke Marine, (Amsterdam, 1993); Alan Lemmers, "Van Holland tot driecilinder: de Onderzeedienst van haar ontstaan tot na de Tweede Wereldoorlog", Robin Snouck Hugronje e.a., Klaar voor onder water. Honderd jaar Nederlandse onderzeedienst, (Zaltbommel, 2006), 10-40.

12 JM Dirkzwager, "De voorgeschiedenis van de opleiding tot scheepsbouwkundig ingenieur aan de Technische Universiteit te Delft", Symposium Marine Scheepsbouw 200 Jaar (1795-1995), (The Hague, 1995), 33-43.

13 JM Dirkzwager, Dr. B.J. Tideman, 128-150, 183-187.

14 Troost, Biografisch Woordenboek van Nederland, on the internet: http://www.historici.nl/Onderzoek/Projecten/BWN/lemmata/bwn3/troost, accessed on 27 March 2012; http://www.marin.nl/web/Organisation/History.htm, accessed 27 March 2012.

15 MARIN is a foundation, performing research projects for paying customers; TNO is essentially a commercial research institute, of which the defence and security branch until 2011 relied heavily on the research funds of the Ministry of Defence - verbal communication by dr. Thijs Brocades-Zaalberg, Netherlands Institute of Military History, The Hague.

16 JL van Soest, Physisch Laboratorium TNO 1927-1977, (s.1., 1977), 58-73. 
of the participants in this very secret project was the firm Hollandsche Signaalapparaten (Signaal) founded in 1922), which after the war became a Philips subsidiary and the home supplier of radar for the RNLN. ${ }^{17}$ One last company that must be mentioned is Van Rietschoten \& Houwens, which became Imtech and since 1896 supplied all electrical installations on board the RNLN ships. ${ }^{18}$

With this we have identified three of the pillars on which Dutch naval shipbuilding after 1945 would rest:

- the Royal Netherlands Navy, prime designer, specialized and innovative partner and star customer;

- an organized shipbuilding, engineering and electronics industry with ties with the RNLN going back in some cases more than one hundred years (all firms identified above);

- a strong research sector (MARIN and TNO) jointly supported by both the state and private industry.

Before we turn to the post-war situation, a brief remark on the geostrategic position of the Netherlands is necessary. Since the proclamation of the German Empire in 1871, the Netherlands found itself wedged in between three great powers: Great Britain, France and Germany. Its command of the mouths of the three major communication lines with the European hinterland, viz. the rivers Rhine, Meuse and Scheldt, provided the Netherlands with some safeguard against its powerful European neighbours, as each of those would deny the others the conquest of these vital strategic lines. With this balance of power the Netherlands was able to maintain a fragile, self-proclaimed neutrality until the outbreak of the Second World War. ${ }^{19}$ With the country quickly overrun by Nazi Germany and its colonies by Imperialist Japan, it was clear that neutrality was no longer an option. Well before 1949, when the Netherlands, under strong international pressure, let go of its Far Eastern colonies, the RNLN was already focussing on an Atlantic and European future in an allied context. ${ }^{20}$

The Treaty of Brussels (1948), NATO (1949), the European Coal and Steel Community (1950) and the Western European Union (1954) outlined the allied commitments for the following decades of the Cold War. In 1948, with an eye on the allied tasks, a fixed division of the Dutch defence budget between the army, the navy and the air force was set at 2:1:1. This fixed ratio would

17 Janet Telders e.a. (eds.), Doorgaan. Beknopte geschiedenis van Hollandse Signaalapparaten B.V. Hengelo 1922-1974, (Hengelo 1974), passim; Thiemo Burger e.a. (eds.), Van oorschelp tot radar. De geschiedenis van een bijzondere onderneming, (Hengelo, 1997), passim.

18 A Leer, F Stout and D Haaksma (eds), Van stoom en wind naar chip en print. Hondervijfentwintig jaar Van Rietschoten en Houwens, (Rotterdam, 1985), 17.

19 Herman Amersfoort and Wim Klinkert (eds.), Small Powers in the Age of Total War, 19001940, (Leiden-Boston, 2011), 251-255.

20 GJA Raven (ed.), De kroon op het anker. 175 jaar Koninklijke Marine, (Amsterdam, 1988), 117; JWL Brouwer, "Dutch naval policy in the Cold War Period", JR Bruijn e.a. (eds.), Strategy and Response in the Twentieth Century Maritime World. Papers presented to the Fourth BritishDutch Maritime History Conference, (Amsterdam, 2001), 42-50, 43. 
repeatedly enable the Navy Board to frustrate government interference in its spending, while additionally it could rely on allied commitments to enforce approval for its fleet program expenditures. ${ }^{21}$ NATO would be of essential influence and can therefore be considered as the fourth pillar of Dutch post-war naval shipbuilding.

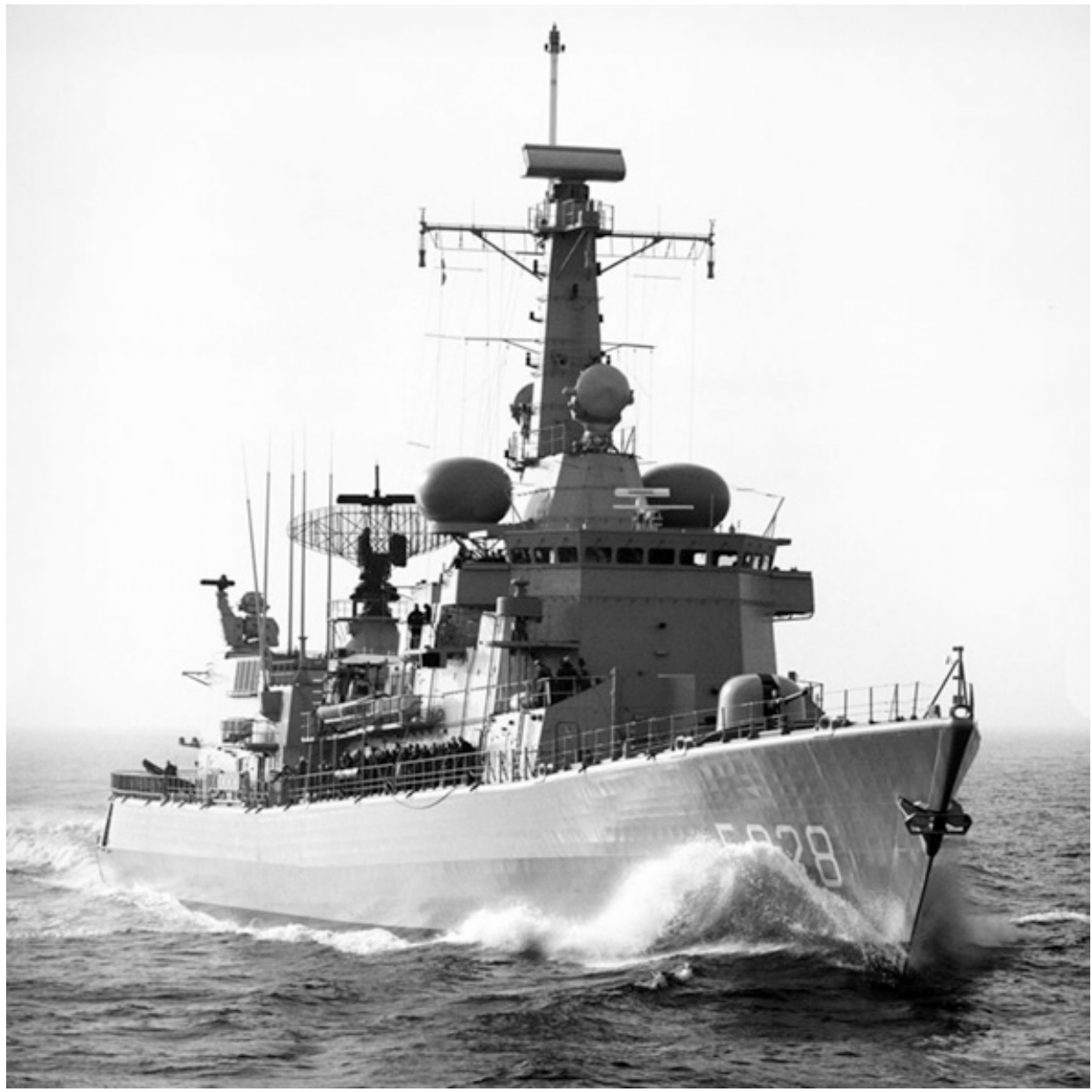

Hr. Ms. Van Speijk (F828) Source: Koninklijke Marine

21 Brouwer, "Dutch naval policy in the Cold War Period", 46; AWG van Oosterhout, De precaire autonomie van de Nederlandse scheepsbouw, (Twente, 2001), passim. 


\section{RESTORATION AND COLD WAR (1945-1989)}

\section{Fleet Program}

At the end of the Second World War the RNLN found itself left with only a fraction of its pre-war fleet, mostly worn out and out of date, while the country's infrastructure and industry were in ruins. The wartime dependency on the generosity of its allies had made the RNLN very keen to have a strong national shipbuilding sector at its direct disposal. As the backbone of trade and heavy industry, as a major employer and finally, because shipping was a vital communication's link with the overseas territories, the shipbuilding sector also enjoyed the attention and support of several other government ministries in addition to defence, such as trade and shipping, industry, and employment. The industry was helped to its feet again as fast as possible, bridging the first hard years with building contracts from the RNLN.

The RNLN faced the massive job of rebuilding a fleet out of nothing and with very limited financial means. On the one hand the organization still begged, borrowed, bought and leased from its American, British and Australian allies. On the other it developed building programs of its own. Within a decade two cruisers and twelve brand new destroyers were built, four three-cylinder submarines of a unique and hypermodern concept were commissioned and six more frigates (Van Speijk class) were planned for the first half of the sixties. The submarine service actually was saved only because NATO demanded at least four operational boats if the Dutch navy was to participate at a decisionmaking level. As in many other Western European countries a huge minesweeping fleet was called into being with massive American aid, partly in kind and partly by funding local building projects (the Mutual Defence Assistance Program or MDAP). ${ }^{22}$ While purchased materiel aged and leasing contracts expired, the fleet program of 1948 was completed by 1960, by which time the RNLN and the shipbuilding industry no longer enjoyed nor needed American aid.

Of the 152 ships acquired in the period before 1962, fifty were built on Dutch yards, providing employment and the opportunity to overcome the war damages. The workload was equally divided across the yards in Flushing, Rotterdam and Amsterdam and some smaller yards for the minesweepers. Naval orders were welcomed, but not in too great a quantity either, as a yard would then be forced to neglect its civil customers. Needless to say Nevesbu provided all the navy plans, and Signaal all sensors. By the mid-sixties Dutch naval shipbuilding and the Dutch fleet were back to full capacity and capable of developing and launching the most advanced platforms, of which the three-

\footnotetext{
22 The MDAP was launched by President Harry Truman on 4 October 1949 and provided material and financial assistance to many European countries.
} 
cylinder submarines (coming into service 1960-1966) and the Van Speijk-class frigates (coming into service 1967-1968) bear witness.

At the height of the Cold War, the RNLN deployed a substantial antisubmarine warfare (ASW) fleet consisting of two Atlantic task forces and a smaller one for the Channel and the North Sea. The only aircraft carrier was sold in 1968. Now that its overall strategy was clear, the RNLN entered into a phase of stability, in which the subsequent building programs focussed on replacement and modernization of existing materiel. ${ }^{23}$ For certain aspects of international (NATO) security, such as ASW, the RNLN belonged in the top three with the United States and Britain. ${ }^{24}$ Meanwhile cooperation with the British Royal Navy in materiel development was intense. The Van Speijk class frigate may serve as an example: it was based on the British Leander class and equipped with the British Seacat surface-to-air missile (SAM), for which the Royal Navy received Dutch 3D radar in return. ${ }^{25}$ In brief, the building programs that followed can be summed up as: one oiler and supply ship (Poolster, 1964), two Zwaardvis class submarines (1966-1972), two guided-missiles frigates (Tromp class or GW-frigates, 1971-1976), a second supply vessel (Zuiderkruis, 1975), twelve "Standard" frigates (Kortenaer class or S-frigates, 1975-1983), four (originally six planned) Walrus class subs (1978-1994), two air-defence frigates (Jacob van Heemskerck class or L-frigates, 1981-1986), fifteen Alkmaar-class or "tripartite" mine-hunters (1981-1989) and eight multi-purpose frigates (Karel Doorman class or M-frigates, 1985-1995). ${ }^{26}$ Finally the 1964 auxiliary Poolster was replaced in 1995 by the Amsterdam.

Starting with the 1970s Tromp class the RNLN exclusively procured US missile systems. Beginning in 1979 the Dutch-American Goalkeeper closein weapon system was added. Under NATO influence the RNLN switched from UK to US standards. As in other parts of the world, a shift from anti-submarine warfare (ASW) to anti-air warfare (AAW) occurred in the early 1980s. The combined input of the pillars of Dutch naval shipbuilding guaranteed the highest quality and technological sophistication, excelling especially in radar and guidance electronics and system integration. Experiments were not shunned and produced some resounding successes, such as the Walrus submarines. (They were not, however without problems.)

23 Brouwer, "Dutch naval policy in the Cold War Period", 47.

24 Amongst other things in SSX exercises - JJ Vaessen, "Fishplay en Long Look", in Marineblad, 117/9 (December 2007), 32-35; Robin Snouck Hurgronje (e.a.), Klaar voor onder water. Honderd jaar Nederlandse onderzeeboten (Zaltbommel-Den Helder, 2006), 43-50 - but also with Atlantic patrol aircraft flying from Iceland and with Marine Corps patrols of the northern NATO border.

25 SG Nooteboom, Deugdelijke schepen. Marinescheepsbouw 1945-1995, (Zaltbommel, 2001), $102,105,124$.

26 The dates refer to the laying of the first keel to the last ship taken into service - Nooteboom, Deugdelijke schepen, passim. 


\section{The Industry}

Before 1940 the shipbuilding industry had made some attempts to enter the international market with naval products, but there was little ambition in that direction after the war. ${ }^{27}$ Rather, the industry diversified in the civil market. Besides ships for the merchant navy, most of the firms were also active in other "heavy metal" sectors: civil engineering, industrial machinery, boilers and energy production, petro-chemistry, automobile and rail transport, even aeronautics and construction. However, from 1965 the shipbuilding sector in Europe deteriorated as a result of rocketing inflation and murderous Asian competition. In order to survive, the sector restructured itself: the companies De Schelde, RDM and Wilton-Fijenoord merged in 1968 to form the Rijn-Schelde Combination. Within this configuration the De Schelde yard took care of naval surface vessels and commercial freighters, while RDM concentrated on submarines and off-shore (oil tankers). At the same time the NDSM yard was taken over by the newcomer Verolme United Shipyards, with the promise of government subsidies. Verolme concentrated on off-shore. Initially it profitted from the Suez Canal crisis (1967-1975), but started losing heavily from 1969 as a result of the explosive rise in wages. With 14.000 jobs at stake and the RijnSchelde Combination facing similar problems, the government in 1971 forced Verolme and the Rijn-Schelde Combination to merge into one conglomerate, "Rijn-Schelde-Verolme" (RSV).

In those days of worldwide depression the Dutch government was not averse to exercising an active industrial policy. It proved a firm believer in merger solutions, adhering to the maxim "Big is Beautiful" ${ }^{28}$ Moreover it actively supported industrial ventures in naval shipbuilding, as can be illustrated with the government subsidised construction docks for the S-frigates at the De Schelde yard, for the Walrus submarines at RDM and for the tripartite minehunters at Van der Giessen - de Noord. The government also accepted the new market situation with respect to naval shipbuilding, where as a result of the Rijn-Schelde merger the principle of public tender had been informally replaced by single-sourcing, with De Schelde for surface ships and RDM for submarines.

The 1970s produced other challenges for Dutch shipbuilding. Oil tankers built in Japan and Korea at rock bottom prices flooded the market even

\footnotetext{
27 Wilton-Fijenoord before the war had built a small number of submarines for foreign powers on plans of the controversial designing bureau Inkavos, actually a Netherlands-based German company with which the Kriegsmarine tried to sustain its designing and building capabilities in spite of the Versailles treaty forbidding German arms manufacture. In the 1980s Wilton would build four corvettes for the Indonesian navy, and for Taiwan two more submarines and two patrol vessels - Hans van der Sloot, Wilton-Fijenoord, (Rotterdam, 1995), 179.

28 Cees de Voogd, "Dutch government policy and the decline of shipbuilding in the Netherlands", Bruijn e.a. (eds.), Strategy and Response, 100-119; JM Dirkzwager, "Verolme, Cornelis (1900-1981)", Biografisch Woordenboek van Nederland - on the internet at www.historici.n1/Onderzoek/Projecten/BWN/lemmata/Index/bwn4/verolme [10-02-2012], accessed 14 May 2012; verbal communication by Willem Laros, Damen Shipyard Group.
} 
as demand was drying up because of the 1973 oil-crisis. In that climate the RSV management turned to speculative production and started to allow for back payments, two fatal mistakes. ${ }^{29}$ Even the commission of the twelve S-frigates (1975-1983) and the successful sale of a handful of naval ships to Indonesia, Taiwan and Greece, were hardly a comfort as long as the civil segment of the industry was losing ground every day. The idea of production cuts was rejected and by 1977 the closure of at least some of the yards seemed inevitable. Yet the state, by now a major shareholder, refused to do so for reasons of employment; the Wilton-Fijenoord yard was even granted the contract for two S-frigates primarily on social grounds. ${ }^{30}$ When in 1978 the government blocked a deal of RDM for nuclear reactors in South Africa because of the anti-apartheid boycott the yard was compensated with an order for six Walrus class submarines.

While RSV management unsuccessfully tried to diversify and reorganize, the state was losing hundreds of millions. In 1983 the company finally foundered at the cost of 5,000 jobs (16,000 in all since 1975) and \$2.5 billion of state funding. Similar catastrophic events in the shipbuilding sectors in Great Britain, the German Bundesrepublik and Sweden in the same period were cold comfort at best. ${ }^{31}$ With some S-frigates and four Walrus submarines still under construction, the government decided to save the yards De Schelde and RDM, which were separated from the RSV conglomerate. ${ }^{32}$ The yards signed a ten-year covenant with the state, now their major shareholder, in which the single-sourcing construction was formalized. ${ }^{33}$ The Verolme and NDSM concerns evaporated, while the Wilton-Fijenoord yard tried to survive on its own. It was actually at that moment building two submarines of the Zwaardvis class for Taiwan. ${ }^{34}$ With some government help the yard was relaunched, but because further navy orders were reserved for the state-yards, De Schelde and RDM, and the Dutch government refused the export license for several foreign naval orders, the building section of the yard shut down in 1988. WiltonFijenoords surviving repair section was taken over by Damen Shipyards Group in 2003 .

\footnotetext{
29 http://www.parlement.com/, accessed 4 April 2011.

30 Nooteboom, Deugdelijke schepen, 133, 136; the planned order of seventeen S-frigates by Iran at the same time also forced the RSV yards to spread their building capacity - verbal communication by drs. AJ van der Peet, Netherlands Institute of Military History, The Hague . 31 De Voogd, "Dutch government policy"; http://www.parlement.com/, accessed 4 April 2011.

32 The De Schelde yard itself was a healthy company, but the RSV management used the yard's profits to fund unsuccessful projects of other parts of the concern. When the rumour of the RSV bankruptcy reached De Schelde, the yard director immediately asked the RNLN to mark all materials on the yard as property of the navy to prevent them from being sequestered by creditors of RSV. Margot Schotel (dir.), De Schelde, vergeten trots, film, Hell-o Films / Omroep Zeeland, 2010.

33 Verbal communication by Willem Laros, Damen Shipyard Group.

34 Van der Sloot, Wilton-Fijenoord, 151, 179;

http://www.dutchsubmarines.com/export/export_chienlung_hailung.htm, accessed 8 May 2012.
} 
The construction of the Walrus submarines at RDM had not been proceeding as scheduled. Although planned since 1966 as replacements of the now twenty-plus year old threecylinder boats, the designs had not reached maturity nor had they been engineered fully when the order was placed. The costs had therefore been estimated only roughly, and with hindsight, too low. ${ }^{35}$ As construction progressed, the projected designs proved so complex that continuous adjustments, model trials and recalculations had to be made.

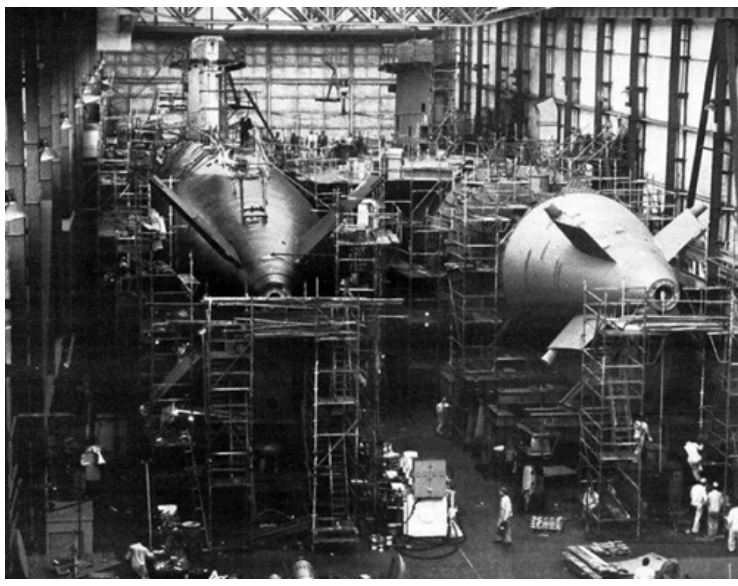

Two Walrus-submarines under construction at the RDM yard in the 1980s Source: Netherlands Institute of Military History (Ministry of Defence) Combined with inflation, the alterations and subsequent delays multiplied the original price estimate threefold. ${ }^{36}$ When in 1984 the financial extravagances, until then concealed by constant budgetary juggling, came to light, the entire management of the RNLN materiel organisation was sacked and government greatly tightened its grip on the procurement policy of the armed forces. ${ }^{37}$ The financial flop resulted in the cancellation of the last two of the submarine series. The four 2500t Walrus submarines, which in spite of the financial debacle have since proven to be the best conventional long distance combat submarines in the world, finally came into service in 19901994.

35 Verbal communication by ir. Jaap Huisman, RNLN.

36 Nooteboom, Deugdelijke schepen, 143-151.

37 As a result of the Walrus debacle, control procedures were developed, known as the "Defensie Materiaalkeuze Proces" (Defence Materiel Selection Process) or DMP - Victor Enthoven, "The LCF Project and its Political Reception, 1989-2004”, F124 and LCF. Lessons Learned and Future Perspectives, (Sankt Augustin, 2004), 18-22. 


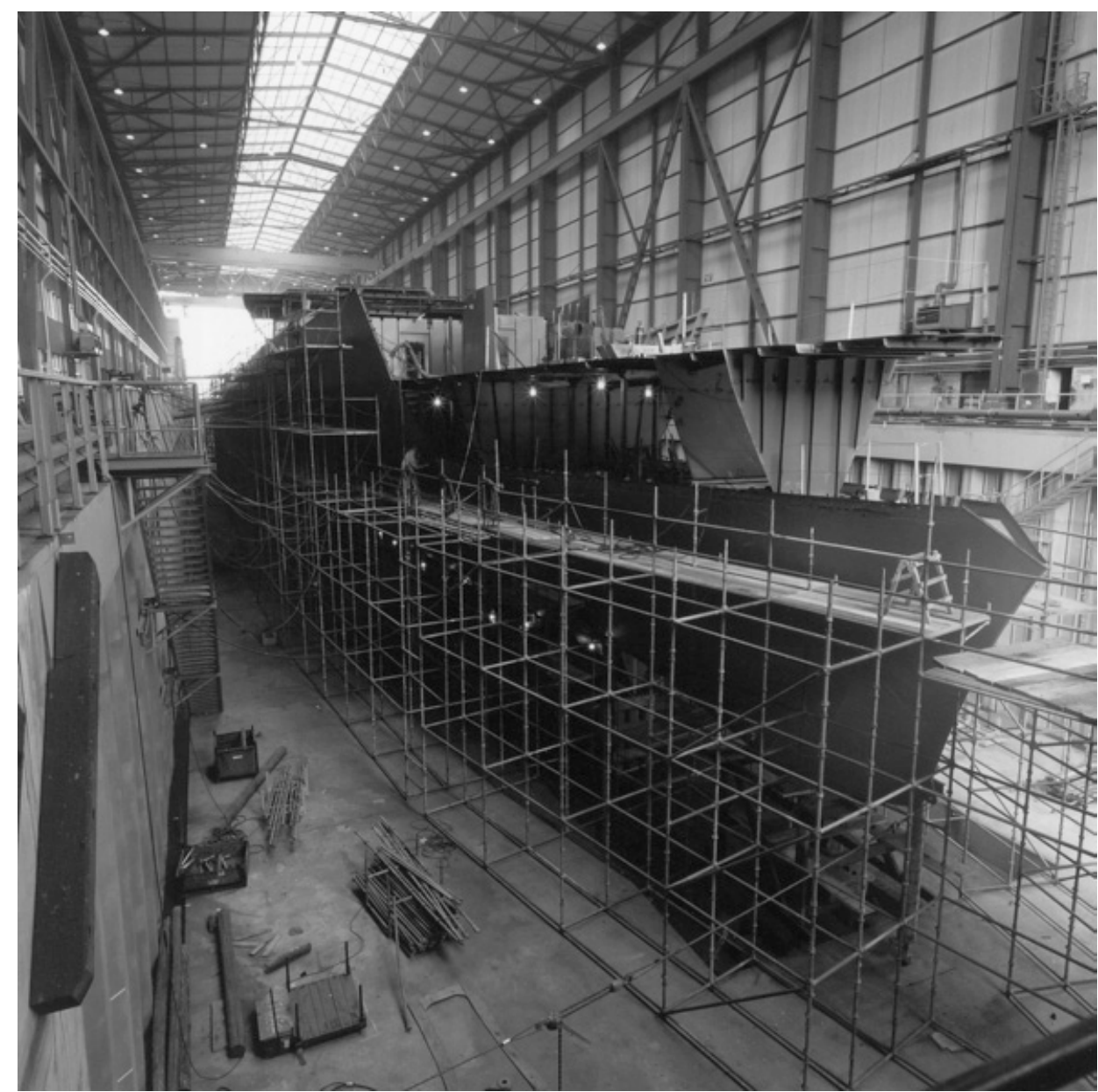

M-frigate under construction at the De Schelde yard. Source: Netherlands Institute of Military History (Ministry of Defence)

The design and production program of the eight M-class frigates was more successful in staying within the budget, even as a number of innovative features were be introduced. A wide application of commercial-off-the-shelf (COTS) products helped control the expenses, living standards were improved significantly, and the use of toxic materials was avoided as much as possible. A substantial reduction of underwater noise levels and radar reflection was achieved, while the rudder roll stabilization to reduce the rolling motion attracted international interest. The experiences of the Royal Navy during the Falkland's War prompted greatly enhanced safety measures such as fire insulation. The use of COTS computers in active damping suspension was a technology that would become widespread only after 2008. However, because the building program was advanced by one year from 1986 to 1985 to secure the survival of the De Schelde yard, the hulls were completed long before the 
envisaged sophisticated combat system had been fully developed. The first Mfrigate sailed in 1991, the eighth and last came into service in 1995, but because of the combat system delays the class was fully operational only by 1996, which caused some damage to the RNLN's reputation. ${ }^{38}$

By the early1970s it had also been clear that the ageing minesweeper fleet would soon be obsolete. For the development of suitable replacements the Netherlands formed a joint venture with France and Belgium, in which France built the mine-hunting equipment, Belgium provided the electronics and the Netherlands the propulsion train. The result was a series| of polyester "tripartite" mine-hunters, built in 1983-1989, of which France and the Netherlands each bought fifteen and Belgium ten. The Dutch mine-hunters (Alkmaar class) were built at the yard Van der Giessen - de Noord. ${ }^{39}$ Minehunters of this type, whether new or used, were subsequently sold to Pakistan, Indonesia, Latvia and Bulgaria. Receiving no more naval orders after 1990 and suffering badly from foreign competition, Van der Giessen - de Noord went into liquidation in 2003.

By the end of the Cold War the Dutch naval shipbuilding industry was thus reduced to two state-owned yards, with Signaal still the major partner in sensor systems. For its gas turbines (starting with the Tromp class of the 1970s) the RNLN had turned to British suppliers (Rolls-Royce). Werkspoor continued supplying diesel engines for the smaller units and once again for bigger ships after the introduction of combined diesel and gas-turbine propulsion. The firm was taken over by the Finish company Wärtsilä in $1989 .{ }^{40}$

Throughout the Cold War the technical departments of the RNLN had remained firmly in the driver's seat of all construction projects. Besides the shipbuilding, engineering and electronics departments, the navy in the course of the 1970s and '80s established its own software engineering division for combat management systems and system integration (SEWACO). This asset has proved very effective and profitable since. When used appropriately, the ready design capability of the combined sections was a powerful tool for cost reduction. In their heyday in the mid-eighties the technical departments had almost five hundred employees. ${ }^{41}$

38 Gijs Rommelse, 'Follow me'. De M-fregatten van de Karel Doorman-klasse, (Franeker, 2008), 33-38.

$39 \mathrm{http}: / /$ www.scheepsbouw-alblasserdam.nl/vandergiessendenoord.htm, accessed 7 May 2012. The yard, Van der Giessen - de Noord, had roots going back to the 17th century family Smit at Kinderdijk near Rotterdam, who founded several yards over the course of time. Arie Smit (18451935) was co-founder of the yard De Schelde in Flushing in 1875. The Smit yard Oude Werf at Alblasserdam (1812) was bought by Cornelis Verolme in 1950. The yard De Noord, founded in 1904 by Jan Ullrich Smit (1863- 1928), became Van der Giessen - de Noord in 1962. In the 19th century the Smit yards at Kinderdijk occasionally built RNLN-vessels in cooperation with the Nederlandsch Stoomboot Maatschappij Fijenoord, which supplied the engines.

40 Nooteboom, Deugdelijke schepen, passim.

41 Verbal communication by ir. Jaap Huisman, RNLN. 


\section{THE NEW WORLD ORDER (1989-TODAY)}

\section{Fleet Programs}

The fall of the Berlin Wall, the dissolution of the Warsaw Pact and the collapse of the Soviet Union in 1989-1991 found the RNLN with an operational fleet of five submarines and fourteen frigates, with eight frigates and four submarines under construction for replacement - all directed at a threat that was rapidly dissolving. Politicians and public opinion alike immediately perceived the chance to get rid of the continuous financial burden of Defence: it was time to "collect the peace dividend." In 1991 the Dutch minister of defence laid out a policy of restructuring and reducing the armed forces, followed two years later by a new strategic concept based on the altered global situation. ${ }^{42}$ The armed forces had to be transformed from a large, traditional and predominantly conscript territorial defence force to a small, mobile, multifunctional and ultramodern professional rapid task force, focussed on crisis management and peacekeeping worldwide. And thus, by turning an operation of cutbacks into one of quality improvement, the minister of defence tried to retain maximum striking power. ${ }^{43}$

The RNLN would continue to emphasize its allied commitments with NATO, but the geostrategic shift to the New World Order was soon perceptible in the tactical choices that were now made. Besides fulfilling the long-felt wish of the RNLN Marine Corps, the 12,750t landing platform dock (LPD) Rotterdam also reflected the shift towards littoral warfare, in line with the ambitions of peacekeeping and crisis handling operations in allied or UN context. The ship was designed and built in a joint venture with the Spanish navy between 1992 and 1998. ${ }^{44}$ In 2001 the RNLN ordered a second, even larger LPD, the 16,000t Johan de Witt, which came into service in 2007. The two ships soon proved their use in allied and UN operations in Albania, Eritrea, Liberia and Somalia.

\footnotetext{
42 Defensienota 1991. Herstructurering en verkleining: de Nederlandse krijgsmacht in een veranderende wereld, (Den Haag, 1991); Een andere wereld, een andere defensie.

Prioriteitennota, (Den Haag, 1993); Relus ter Beek, Manoeuvreren. Herinneringen aan Plein 4, (s.1., 1996), 135-171, 169.

43 Ter Beek, Manoeuvreren, 62-63.

44 The Spanish LPDs Gallicia and Castilia were completed in 1998 and 2001 respectively; despite the joint venture they differ with the Dutch LPD on critical points such as direct diesel propulsion vice diesel-electric propulsion.
} 


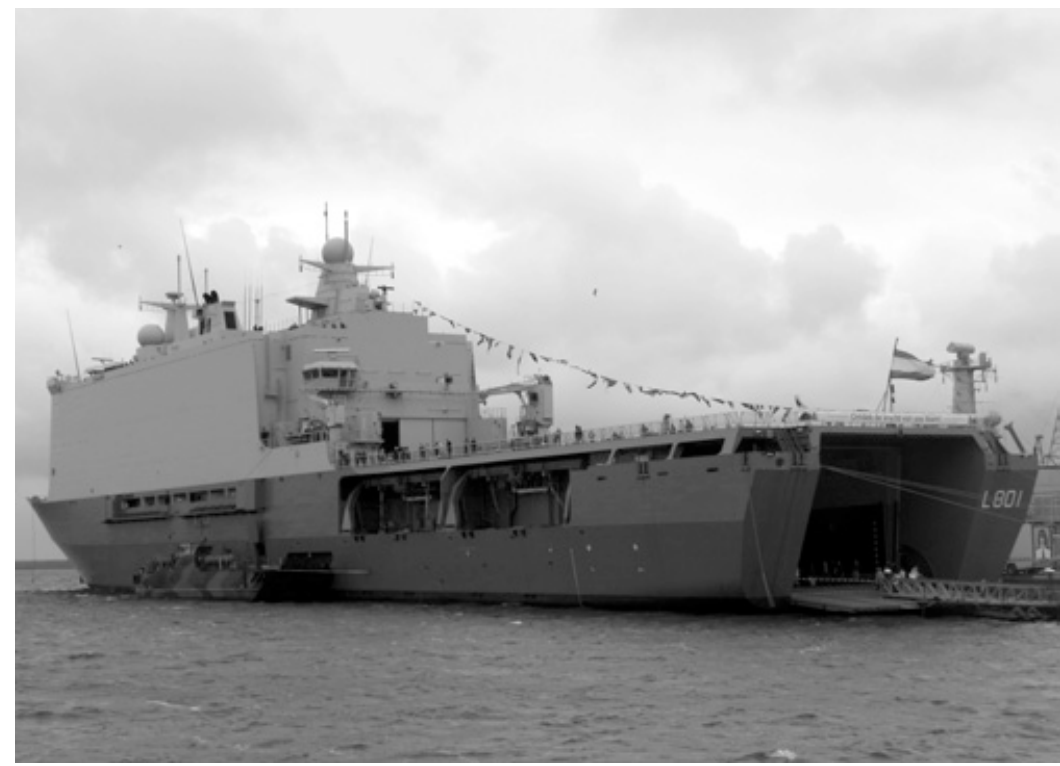

Johan de Witt (L801) Source: Ministry of Defence

Meanwhile there were still ties with the past: after the collapse of the NATO Frigate Replacement for the Nineties program (NFR-90s) - one of the international cooperation programs initiated by NATO in an attempt to maximise standardisation and interoperability within its naval forces - the RNLN sought alternatives for the replacement of the 1970s GW-class frigates and the 1980s L-frigates. ${ }^{45}$ In 1994 the Dutch LCF (air-defence and command frigates), the German F124 and the Spanish F100 programs joined forces in a Trilateral Frigate Cooperation (TFC). Spain opted for an American AAW system in 1995, but the Netherlands and Germany went for joint procurement of the platform systems and joint software engineering. Together with ThalesNederland (formerly Signaal) a multiple-target air and surface search, tracking and guidance radar (APAR: Active Phased Array Radar) was developed, which is paired with a Signaal long distance radar (SMART-L), capable of detecting incoming targets at distances up to $500 \mathrm{~km}$, a technology that not even the US Navy had at its disposal at the time. ${ }^{46}$ Four 6000t LCFs (De Zeven Provinciën class), partly financed by the early decommissioning and selling of a number of S-frigates, came into RNLN service in 2002-2005.

\footnotetext{
45 Van Oosterhout, De precaire autonomie van de Nederlandse scheepsbouw, 177-201; Enthoven, "The LCF Project and its Political Reception," 20.

46 F124 and LCF. Lessons Learned and Future Perspectives, (Sankt Augustin, 2004), passim; verbal communication by ir. Jaap Huisman, RNLN; "Nederland verrast Amerikanen", in Defensiekrant (12 december 2006), 4-5; Monique van Rijen, 'Hr.Ms. Tromp heeft antwoord op ballistische raketaanval', in Alle Hens (2007/1), 8-9.
} 
The LPD and the LCF programs also bear witness to the fact that the independent development by medium-sized powers of large, complex naval units was becoming a thing of the past: medium-sized powers can only keep up by pooling their efforts in multinational ventures. ${ }^{47}$ International scientific and technological cooperation is increasing in NATO, EDA (European Defence Agency) and bilateral contexts. The cooperation between the Netherlands and Germany has been especially good since the 1990s' LCF-project. The geographic differences in the operating areas of each navy generally form the main obstacles for successful cooperation, but they can be overcome, as the LCF-F124 project showed. ${ }^{48}$

It is not irrelevant to point out that at the time the LCFs were ordered, the economy was booming and financial obstacles were of secondary importance. But the world was moving to different and more turbulent times. In the first years of the 21 st century the call for defence cutbacks increased and the ministry was forced to reorganise and contract the armed forces time upon time. In these uncertain times the continuous replacement policy of the RNLN building programs was no longer obvious. With the active reorientation of Dutch security policy in the New World Order and the consequent far-going reorganization of the Netherlands armed forces in 2005, the grip of the

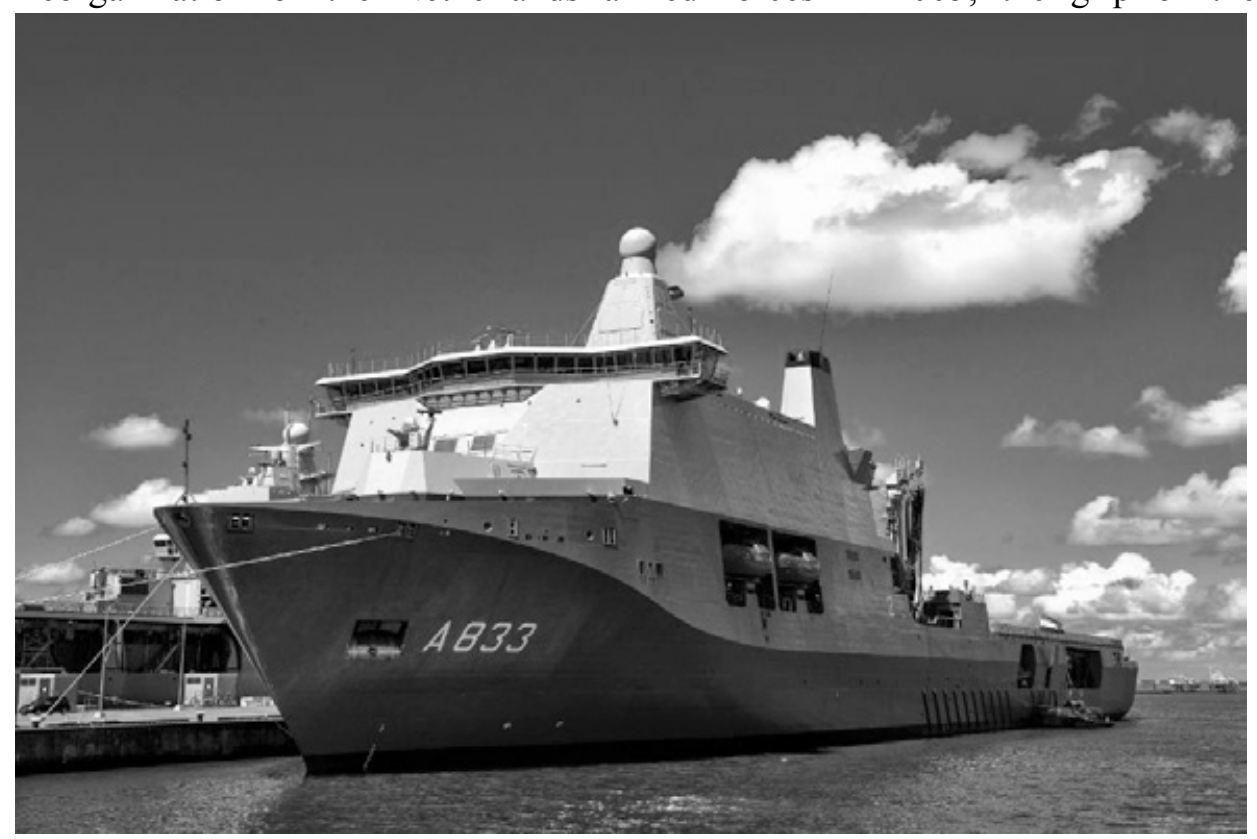

Karel Doorman (A833) Source: Ministry of Defence

47 Many other examples of technological cooperation of the RNLN with the USA, Britain, France, Spain, Germany, Belgium and Denmark can be cited, mostly concerning components of weapons systems.

48 F124 and LCF, 39-44. 
government on the fleet policy was tightened even more than in 1983. Materiel procurement was detached from the operational forces and concentrated in a joint section for the army, navy and air force, the Defence Materiel Organisation (DMO) - with mixed approval. The old 2:1:1 ratio was abandoned. NATO was no longer a valid excuse. For the first time the navy was compelled to formulate a naval doctrine as part of a national defence doctrine and based on international forecasts, thereby providing a binding context within which the fleet policy is determined and can be controlled. ${ }^{49}$ Combined with the financial blood-letting due to the simultaneous economic and banking crises, and with drastic budget cuts on national defence as a result, the capabilities of the navy were seriously reduced.

A 2004 strategic study at the request of the so-called maritime cluster, a consortium of yards and suppliers of the shipbuilding sector, suggested that the RNLN would in future require a much smaller vessel for humanitarian and law enforcement duties, especially in the Caribbean. ${ }^{50}$ But as the existing frigates could perform these tasks for the time being, the proposal was set aside and the RNLN placed no orders. A hue and cry rose from the shipbuilding sector that naval shipbuilding in the Netherlands was facing extinction. To the ultimate relief of the De Schelde yard, by then part of Damen Shipyards Group, the idea was reconsidered in 2006 and a 3750t offshore patrol vessel (OPV, Holland class) was developed over the next years. ${ }^{51}$ Four vessels were planned and the first keel was laid in late 2008. Four M-frigates were decommissioned to make way for the new class. Three of the hulls were built at Damen Shipyards Galati in Rumania, to be finished at De Schelde in Flushing where the fourth hull was built. Because of further major defence cutbacks in 2011 one pair risked being sold abroad, but thanks to sacrifices elsewhere in the organisation the entire class was rescued for RNLN service. ${ }^{52}$ Although the size of a small frigate, the OPVs have a considerably reduced weapons system and are much slower. In their current version with a crew of only fifty and an emphasis on highly sophisticated sensor equipment, they are tailored to low-intensity tasks.

In 2009 the RNLN placed the order for a 28,000t Joint Support Ship (JSS), as the long overdue replacement of the auxiliary Zuiderkruis. Together with the LPDs this ship completes the amphibious plans of the RNLN and with

\footnotetext{
49 Leidraad Maritiem Optreden. De bijdrage van het Commando Zeestrijdkrachten aan de Nederlandse krijgsmacht, (Den Helder, 2005).

$50 \mathrm{http}: / / w w w . t r o u w . n l / t r / n l / 4324 /$ nieuws/archief/article/detail/1745696/2004/10/19/Wervenverliezen-kennis-zonder-nieuwe-korvetten.dhtml, accessed 4 April 2011; http://scheepsbouw.maritiemnieuws.nl/artikel/1221/marinescheepsbouw_dreigt_verloren_te_gaan, accessed 4 April 2011 $51 \mathrm{http} / / /$ binnenland.nieuws.nl/53230, accessed 4 April 2011; http://nl.nntp2http.com/defensie/marine/2006/06/44f822d5544fab9ebd589f0e53c4e9a9.html, accessed 4 April 2011; http://markt.vaart.n1/log/pivot/entry.php?id=150, accessed 4 April 2011. $52 \mathrm{http} / / /$ marineschepen.nl/marschepen/holland.html, accessed 12 January 2012.
} 
its 9,800nm range underscores the RNLNs lasting global ambitions - the JSS Karel Doorman came into service in January $2015 .^{53}$

\section{The Industry}

In the changing climate of neoliberal politics and corporate globalization the industrial sector also underwent drastic changes. Signaal, the cornerstone of Dutch naval radar technology and combat management systems, in 1989 became part of the French state-owned company Thomson CSF, which in 2000 became the international Thales Group. With operations in fifty countries and 68,000 employees, Thales is a world leader in mission-critical information systems for defence and security. ${ }^{54}$ Although the subsidiary Thales-Nederland (the former Signaal) is now part of this multinational, the Dutch state still owns shares in the Dutch Thales member and can veto the export of sensitive products. As long as the RNLN continues to work with US weapons systems, the sensor systems and their integration into the combat system also distinguish themselves as typically Dutch with respect to the products of the French mother firm.

The electric engineering firm Van Rietschoten \& Houwens, since 1967 part of the International Muller conglomerate, was renamed Imtech in 1993. It grew to 25,000 employees with 450 locations across Europe,${ }^{55}$ but foundered on 13 August 2015. What will become of its divisions is as yet unclear.

By the early 1990s, the 1983 government covenant with De Schelde and RDM was running to its close. In $1991 \mathrm{RDM}$ was sold to the Royal Begemann Group, a privately-owned holding company with more than 140 subsidiaries. The parting gift to RDM was the modular Moray class submarine design especially aimed for the international market, developed by Nevesbu in cooperation with the RNLN during the construction of the Walrus series. It incorporated the latest submarine technology and could be delivered in a 1100t, $1400 \mathrm{t}$ or $1800 \mathrm{t}$ submerged version. Nevesbu, of no more use to the other shipyard-shareholders, was sold to RDM for one dollar. ${ }^{56}$ In 1994-2000 RDM tried to sell the Moray design to Portugal, Egypt and Malaysia. Deals fell through at the last moment for different reasons. When finally in 2001 Taiwan was on the verge of buying eight Moray submarines, the Netherlands government again intervened, referring to a 1984 agreement with China not to

\footnotetext{
53 The keel was laid down at the Damen shipyard in Rumania in June 2011 was finished at the Damen De Schelde yard in Flushing. Besides extensive roll on/roll off facilities, the ship has a helicopter deck with a landing area for two and a hangar for six Chinooks, a holding capacity of $10,000 \mathrm{~m}^{3}$ for fuel, helicopter fuel and drinking water, and for 40 tons of ammunition, staff accommodation and a hospital -

http://www.defensie.nl/actueel/nieuws/2009/11/04/46138774/Parlement_geinformeerd_over_ver werving_ondersteuningsschip, accessed 12 May 2012.

$54 \mathrm{http}: / /$ www.thalesgroup.com/NLHome/, accessed 6 April 2011.

$55 \mathrm{http} / / / \mathrm{imtech} . e \mathrm{e} / \mathrm{NL} /$ corporate, accessed 6 April 2011.

56 Verbal communication by Willem Laros, Damen Shipyard Group.
} 
sell weapons or weapon technology to Taiwan. ${ }^{57}$ The company subsequently ran into difficulties and finally foundered in 2007 , without having sold a single submarine. ${ }^{58}$ The technology incorporated in the design remains under the Dutch Defence Secrets Act to this day. ${ }^{59}$ With RDM gone the Netherlands de facto lost its industrial infrastructure for submarine building. Nevesbu in the end was saved by IV Group, a large Dutch engineering firm operating in a wide range of fields. Although still active in naval and submarine design, Nevesbu for a long time no longer worked for the RNLN; today it is again employed in the life extension program of the Walrus submarines. ${ }^{60}$

In 1993 the Netherlands government voiced its intention to get rid of its shares in De Schelde. In the search for takeover bids the company found no party interested in the combination of shipbuilding and land activities. Therefore in 1997 all the land divisions were dismantled or sold, a social catastrophe for Zeeland. ${ }^{61}$ The RNLN declared its ardent desire for the yard to remain in Dutch ownership, especially since the French take-over of Signaal. In 2000 a suitable takeover candidate was found in Damen Shipyards Group, to which the yard was sold for one dollar. Damen had emerged from a family business in 1969. It concentrated on standardized designs and modular shipbuilding, mainly of smaller craft. ${ }^{62}$ The recession in the early 1980 s created the opportunity to take over shipyards that had run into hard times, thus increasing both the company's production volume and diversity. Besides shipyards, Damen acquired repair yards and engineering works throughout the country. The expansion continued to shipyards abroad, preferably in low wage countries. The acquisition of a growing number of foreign customers meant local maintenance and repair facilities were founded across the globe. For major shipbuilding, the company acquired shipyards in Poland, Rumania, Singapore, Sweden and China. Its modular design and building technique is very successful in commercial shipbuilding, varying from tugs to ferries, crewtenders, fishing vessels, dredgers and even yachts. ${ }^{63}$ With RDM gone, Damen became the sole remaining naval shipbuilder in the Netherlands.

\footnotetext{
57 http://www.dutchsubmarines.com/export/export_moray.htm, accessed 3 November 2011; http://www.nti.org/db/submarines/netherlands/export.html, accessed 13 December 2011; http://www.globalsecurity.org/military/world/taiwan/hai-lung-2.htm, accessed 13 December 2011; http://www.dutchsubmarines.com/export/export_taiwan.htm, accessed 8 May 2012.

$58 \mathrm{RDM}$ for some time also produced land army vehicles and in vain tried to start up helicopter production. The Begemann holding also crumbled within years, as the result of the financial adventures of the owner Joep van den Nieuwenhuizen.

59 Overheid.nl: https://zoek.officielebekendmakingen.nl/dossier/26396/kst-31200-X-44.html, accessed 13 December 2011.

60 Today half of Nevesbu is owned by Damen, the other half by IV-Group; http://www.ivgroep.nl/nl/iv-bedrijven/nevesbu.html, accessed 6 April 2011; verbal communication by ir. Jaap Huisman, RNLN.

${ }^{61}$ Verbal communication by Willem Laros, Damen Shipyard Group; Margot Schotel (dir.), De

Schelde, vergeten trots.

62 http://www.damen.nl/en/about/a-family-history, accessed 7 May 2012.

63 http://www.damen.nl/PRODUCTS/index.aspx.aspx?mId=8563, accessed 4 April 2011.
} 
Damen offered De Schelde an extensive global marketing and sales organisation and the use of foreign, cheap building yards. During the search for takeover candidates in the 1990s, De Schelde had developed its own modular lines of naval units for the international market, leaning on its long experience with RNLN designs. This fit extremely well with the Damen philosophy. ${ }^{64}$ The 1997 Enforcer line, based on the Dutch-Spanish LPDs, was used by the Royal Navy for its Bay class landing ship series. ${ }^{65}$ The successful Sigma line is a modular design covering the whole spectrum from offshore patrol vessels to corvette to light frigates, ranging from fifty to one hundred and fifty metres in length and nine to fifteen metres in beam. ${ }^{66}$ In this series Damen has built naval units for Indonesia and Morocco and coastguard vessels for Sweden, each time customizing the modular lines to the client's wishes.

For the takeover of De Schelde, Damen set the condition that the single sourcing relationship with the RNLN was prolonged for all projects then in development, ending with the joint support ship. The Damen Schelde Naval Shipbuilding division treasures its relationship with the RNLN as the prime source of conceptual and technological progress. The ships built for the RNLN are all conceived by the RNLN itself and qualitatively of another league than the Damen custom-built serial products for foreign - and mostly small - navies. Despite being reduced in size by more than half since the mid 1980s, the ability of the technical departments of the RNLN to translate operational needs and experience into revolutionary materiel concepts remains crucial to Damen's own design progress. ${ }^{67}$

\section{THE PILLARS REVISED}

Beginning with the Cold War and continuing to 2001, the Royal Netherlands Navy enjoyed luxurious times. As a medium sized and relatively rich navy it could lay out a fairly autonomous fleet policy, in which it was continuously able to optimize its combat vessels to the highest technical perfection. Naturally this resulted in a relative increase of the costs per naval unit, which in turn gradually forced the RNLN to reduce the size of the fleet. However, despite the strategic turn-around after the fall of the Iron Curtain and the economic crises of the last decade with massive cutbacks for the Dutch armed forces, the RNLN managed

64 Verbal communication by Willem Laros, Damen Shipyard Group.

65 Damen Schelde Naval Shipbuilding, Enforcer Series, prospectus, no date; http://www.royalnavy.mod.uk/The-Fleet/Royal-Fleet-Auxiliary/Bay-Class-Landing-Ships, accessed 16 May 2012; http://www.naval-technology.com/projects/bay_class/, accessed 16 May 2012.

${ }^{66}$ Damen Schelde Naval Shipbuilding, Sigma Naval Patrol Series, prospectus, no date; http://www.damennaval.com/nl/main-stream-activities_combatants-and-opv\%2527s_sigmaseries.htm, accessed 21 December 2011.

${ }^{67}$ The RNLN also facilitates Damen with the trials of the vessels built for foreign navies and the training of their crews - verbal communication by Willem Laros, Damen Shipyard Group. 
to maintain a diversified combat fleet. Today it includes six frigates, four submarines, two LPDs, four ocean patrol vessels, six mine-hunters and a joint support ship. The strategic shift is reflected in completely new concepts for specific tasks. The Walrus submarines and Alkmaar mine-hunters currently are being upgraded as their usefulness is reappraised in the light of recent shifts in the nature of international conflict.

Together these highly sophisticated units are employable in operations ranging from task force command and theatre ballistic missile defence to land operations' support, intelligence missions, piracy control and sea policing. However its continued size reduction over the last decades has been sorely felt. This has led the RNLN to compensate through close cooperation with the Belgian navy - so close it has recently has been referred to as "complete integration". 68 The increasing sophistication and costs of combat systems have likewise resulted in growing multinational cooperation in the area of platform systems development, a trend that appears will be permanent. ${ }^{69}$

At home the RNLN for a long time played the dominant and guiding role of lead firm for the Dutch naval shipbuilding industry, both in R\&D and in ship design. Its position as star customer at times resulted in a far reaching dependency of the companies on naval contracts, while Dutch foreign policy has regularly frustrated export opportunities. ${ }^{70}$ After the 1980 s disaster following government involvement in the heavy industry sector, the RNLN alone was unable to save all the yards. However, the single sourcing practice of the last thirty years has worked out fairly well both for the RNLN and its industrial partners. It has safeguarded a reliable domestic industrial potential for the navy and supplied the industry with indispensable technological and conceptual input, thus keeping it at level with the international naval market. Although at face value it is in conflict with recent European market regulations, the gains in efficiency and reliability of this deal are deemed more important than (former) arguments of employment and/or a competitive business climate.

At the international level the units of the RNLN rank with the top of naval defence materiel in conceptual design and sophisticated execution. For a large part this was the result of the work of the technical divisions of the RNLN. More recently it has been achieved through cooperative ventures with allied navies. The second pillar of Dutch naval shipbuilding, the industry, went through rocky times and was finally reduced to Damen, Thales-Nederland, with platform construction temporarily in a formal single sourcing relationship with its star customer. The third pillar, research (with MARIN and TNO), remained intact and continues to be available for Dutch national defence and any number of private customers. But ultimately the fate of the RNLN fleet depends

\footnotetext{
68 New Year's speech of the commander of the Royal Netherlands Navy, Vice Admiral M.J.M. Borsboom, 11 January 2012. He was referring to operations; for the last 25 years the German navy has been the RNLNs closest ally for technology and materiel development.

69 Verbal communication by ir. Jaap Huisman, RNLN.

70 Van Oosterhout, De precaire autonomie van de Nederlandse scheepsbouw, passim.
} 
foremost on the international environment. NATO, the fourth pillar, for a long period determined both the fields of operation and the materiel requirements for allied cooperation. Today the future of international conflict and alliance is far less clear. In the period we have considered the RNLN redirected its focus from ASW to AAW and then widened it to littoral warfare (with sea based power projection from LPDs and LCFs), and peacekeeping in varied allied and joint settings (OPV and JSS). These shifts all reflected the developments in the nature of naval conflict and maritime law enforcement. A defence policy, which obviously determines the materiel policy, is based foremost on predictions in international security and the strategic estimates derived thereof, which as a historian I gladly leave to others. 
